\title{
Ethnomathematics: Mathematical Concept in the Local Game of Tong Tong Galitong Ji for High School
}

\author{
Turmudi Turmudi \\ Postgraduate mathematics education of State Islamic University of Maulana Malik Ibrahim \\ Malang, Indonesia ORCID 0000-0003-4803-0260
}

\author{
Elly Susanti*
}

Postgraduate mathematics education of State Islamic University of Maulana Malik Ibrahim Malang, Indonesia, ORCID: 0000-0001-9528-4947

Dewi Rosikhoh

Postgraduate mathematics education of State Islamic University of Maulana Malik Ibrahim Malang, Indonesia, ORCID 0000-0001-7017-2586

\author{
Marhayati Marhayati \\ Postgraduate mathematics education of State Islamic University of Maulana Malik Ibrahim \\ Malang, Indonesia ORCID 0000-0001-7092-8080
}

\begin{tabular}{|c|c|}
\hline Article & \multirow{8}{*}{$\begin{array}{l}\text { The aim of this research was to describe the results of the exploration of } \\
\text { mathematical concepts in Malang City's traditional game Tong Tong } \\
\text { Galitong Ji or Nasi Goreng Kecap. This research is a qualitative study } \\
\text { with an ethnographic approach. Data were collected through field } \\
\text { observations, documentation (photographing and video recording), and } \\
\text { in-depth interviews. Data analysis to explore the internal structure of } \\
\text { mathematical concepts in the five stages of the game Tong Tong } \\
\text { Galitong Ji was performed by taxonomic analysis. Exploration of the } \\
\text { concept of basic mathematical operations (addition, subtraction, and } \\
\text { multiplication) occurs in stages one through five, exploration of the } \\
\text { concept of arithmetic modulo } 6 \text { and } 3 \text { operations in stages two through } \\
\text { four, and exploration of the concepts of arithmetic sequence and } \\
\text { probability in stage five of the game Tong Tong Galitong Ji. Stage five } \\
\text { features basic mathematic operations of addition, subtraction, and } \\
\text { multiplication (division excluded), as well as the concept of arithmetic } \\
\text { sequence during the determination of punishment quantity. Punishment } \\
\text { quantity is determined by operating any one of the numbers } 10,4 \text {, and } 7 \\
\text { decided on in stage three with a natural number (ji, ro, lu,..., n) in stage } \\
\text { five. The concept of probability also appears in stage five during } \\
\text { simultaneous finger showing. }\end{array}$} \\
\hline Receiv & \\
\hline & \\
\hline $\begin{array}{l}\text { Received in revised form: } \\
15.06 .2020\end{array}$ & \\
\hline $\begin{array}{l}\text { Accepted: } \\
06.07 .2020\end{array}$ & \\
\hline & \\
\hline & \\
\hline & \\
\hline
\end{tabular}

\footnotetext{
*Correspondency: ellysusanti@ mat.uin-malang.ac.id
} 


\section{Introduction}

Ethnomatematics is mathematical knowledge which grows and develops in a country's culture (Fitriatien, 2017; Massarwe, Verner, \& Bshouty, 2013; Simamora, Saragih, \& Hasratuddin, 2018; Verner, Massarwe, \& Bshouty, 2019; Zhang, 2010). Mathematical concepts may be invented from a given cultural process in a scientific fashion without the need to go through any formal education process (Zayyadi, 2015). Mathematical knowledge in a culture can be found in the language, customary rituals, traditional houses, dances, songs, music, traditional attires, handicrafts, and traditional games (Johnson, 2017; Suherman, 2018). Some research works on ethnomathematics in culture have been carried out on, among other things, traditional games (Dosinaeng, 2010; Febriyanti, Kencanawaty, \& Irawan, 2019; Febriyanti, Prasetya, \& Irawan, 2018; Fouze \& Amit, 2018; Jaelani, Putri, \& Hartono, 2013; Muzdalipah \& Yuliaanto, 2015; Rahmawati \& Dintarini, 2020; Risdiyanti, Charitas, \& Prahmana, 2018; Safitri, Hartoyo, \& Nursang, 2015; Siregar, Solfitri, \& Roza, 2018; Susanti et al., 2020; Utami et al., 2018). For instance, it was found that the game of card dominoes employs an integration of probability theory and higher-order thinking skills (Alghadari \& Son, 2018). In another study, it was also found that mathematical games on the phone and computer are practical and effective to be applied in mathematics instruction (Vandercruysse et al., 2016).

Some traditional Israeli games which contain mathematical values and are applicable to promote mathematical thinking skills are ta'ab (stick game), mozkat (5 stone game), and seega. These traditional games contain such mathematical concepts as length, height, depth, symmetry, to name a few (Fouze \& Amit, 2018). Meanwhile, traditional games in the land of Hausa (northern Nigeria) include the concepts of algebra, set theory, geometric coordinates, arithmetic progression, and geometric progression (Yusuf, Saidu, \& Halliru, 2010). Engklek Geometry can be used as a mathematics instruction medium for rectangular material (Utami et al., 2018). The Minangkabau traditional game stick, on the other hand, can be used to promote number sense, basic principles of such operations as addition and multiplication, place value, and base symbol (Nofrianto, 2015).

Engklek (hopscotch) and gasing (top) are Sundanese traditional games with elements of mathematics. Engklek, for instance, contains the element of two-dimensional geometric shapes like square, rectangle, and semi-circle as well as the element of counting. As for gasing, an element of cylinder is featured (Febriyanti et al., 2018). Traditional games of Javanese folk, especially the ones in Yogyakarta, such as Kubuk, Kubuk Manuk, Dhukter, Macanan, and Jegjegan, cover mathematical concepts like arithmetic operations, two-dimensional shapes, similarity, congruence, comparison of numbers, and relation (Risdiyanti \& Prahmana, 2018). Then, there is the game of kelereng (marbles) which can train motoric, cognitive, and computing skills (Febriyanti et al., 2019).

Malay folk game Sambas incorporates the concepts of integers, distance, time, probability, counting integers, set, two-dimensional shapes, measurement, operations of integers, symmetry, sequence, and series (Safitri et al., 2015). Kampung Naga inhabitants also have their traditional games, namely congklak, galah, and pecle. Congklak carries the concepts of arithmetic operations and modulo, galah probability, substraction, and addition, while pecle geometry, reflection symmetry, and nets of solids (Muzdalipah \& Yuliaanto, 2015). Congklak per se is used in mathematics instruction to introduce the concepts of addition, subtraction, multiplication, and division of numbers (Siregar et al., 2018). It is especially useful in instilling the concept of integers subtraction through instruction (Muslimin, 2012). Lamaholot tribesmen's traditional games of kemoti, kayo raya, and eda also have elements of 
ethnomathematics. Kemoti aids the learning of counting and multiplication, kayo raya does addition and multiplication, and eda does probability (Dosinaeng, 2010).

A considerable number of prior studies are in consensus that traditional games contain elements of ethnomathematics (Alghadari \& Son, 2018; Dosinaeng, 2010; Febriyanti et al., 2019, 2018; Fouze \& Amit, 2018; Jaelani et al., 2013; Muzdalipah \& Yuliaanto, 2015; Rahmawati \& Dintarini, 2020; Risdiyanti \& Prahmana, 2018; Safitri et al., 2015; Siregar et al., 2018; Susanti et al., 2020; Utami et al., 2018). Hence, traditional games are not mere play but also an avenue of extracting educative benefits (Febriyanti et al., 2018). One of traditional games that exhibit hints of ethnomathematical elements is Tong Tong Galitong Ji (hereafter TTGJ), a traditional game in Malang. It is also popular by the name Nasi Goreng Kecap, which is short for naga, singa, gorilla, renggo (rango), kelelawar, capung (dragon, lion, gorilla, renggo, bat, dragonfly). The six names of animals are essentials for this game. The game which takes only the fingers to play is played by a maximum of 6 players through 5 stages. In the first stage of selection, each player is allowed to make one pick from the 6 names of animals and determine what penalty to be imposed (to the punished) should he/she wins the game. In the second stage of elimination, the players use the keyword na-si-go-reng-ke-cap. In the third stage, base numbers are set, with the players using the keyword se-pa-tu, which is short for sepoloh-papat-pitu (ten, four, seven). The fourth stage is for arithmetic operations, and the key phrase used is tambahkali-kurang (add, multiply, subtract). In the last stage, the number to be subjected to an operation with a base number is determined.

The description above shows that mathematical concepts are present in the game of TTGJ. This leads to the question, what ethnomathematical elements are there in TTGJ? It is thus necessary to perform an investigation to identify the elements of ethnomathematics that are present in the game.

\section{Methodology}

This research is a qualitative study with an ethnographic approach, an empirical, theoretical approach performed by observing the language, behavior, actions, and culture of a society. Data were collected through in-depth interviews, documentation (photographing and video recording), and literature study. Observations were carried out on two groups of junior high school students who were playing TTGJ during break time. One group was comprised of 6 players, while the other 5 . The researchers also kept watch of the game played by 4 teen players in the neighborhood. How the game proceeded in each stage was analyzed in this research. The researchers captured photographs and took note of important events during the observations. After the observations, the researchers conducted interviews with players from different groups. Important notes were taken from the interviews. These interviews were intended to gather information regarding the terms used in the game. Then, in the literature study, the data were analyzed by taxonomic analysis technique to explore the mathematical concepts found in each TTGJ stage.

\section{Results and Discussion}

TTGJ (Nasi Goreng Kecap) is a traditional game which uses the players' fingers as the only equipment. It is played by children and adolescents alike, two to six in total. It is divided into 5 stages as detailed in Table 1. 
Table 1. Details of TTGJ stages.

\begin{tabular}{|c|c|}
\hline Stage & Details \\
\hline 1 & $\begin{array}{l}\text { Preparation stage } \\
\text { Each player chooses between dragon, lion, gorilla, renggo, bat, and dragonfly as his/her } \\
\text { identity. } \\
\text { Each player decides on what penalty to be imposed. }\end{array}$ \\
\hline 2 & $\begin{array}{l}\text { Elimination stage, keyword: na-si-go-reng-ke-cap } \\
\text { Each player extends his/her fingers freely. } \\
\text { One of the players points at the fingers extended while spelling "na-si-go-reng-ke-cap." } \\
\text { Every syllable is to one finger. } \\
\text { The syllable uttered at the last finger pointed serves as a reference for eliminating a player. } \\
\text { If the syllable used to rule out the player is pronounced the next time, the player must reenter } \\
\text { the game. } \\
\text { This goes on until only one player remains. It is this player who will be given the penalty. }\end{array}$ \\
\hline 3 & $\begin{array}{l}\text { Number I determination stage, keyword: se-pa-tu } \\
\text { The players extend their fingers again. } \\
\text { One of the players points at each finger extended while spelling "se-pa-tu," each syllable to } \\
\text { one finger. As previously explained, se-pa-tu is short for the numbers ten, four, and seven. } \\
\text { The syllable for the last finger serves as a selected base number. For instance, if at the last } \\
\text { finger the syllable "pa" is uttered, then the base number selected is four. }\end{array}$ \\
\hline 4 & $\begin{array}{l}\text { Arithmetic operation stage, keyphrase: tambah-kali-kurang } \\
\text { The players extend their fingers again. } \\
\text { One of the players points at the fingers extended while saying "tambah-kali-kurang." Each } \\
\text { word is to one finger. } \\
\text { The operation selected is the one said the last. }\end{array}$ \\
\hline 5 & $\begin{array}{l}\text { Execution stage, keyphrase: TTGJ and galagatung ji } \\
\text { This stage is played by two players in turn, one the punished and the other the one out of the } \\
\text { game. } \\
\text { Both players make a fist of the right hand and open the left hand. } \\
\text { The players then strike the left hand with the right fist while saying "tong tong galitong ji." } \\
\text { At "ji" each player points a finger to the right at the same time as the other. If the fingers } \\
\text { pointed by the two players are the same, the game is over. The penalty will be the base } \\
\text { number obtained in the third stage. But if the fingers pointed are different, the game } \\
\text { continues. } \\
\text { Both players strike the left hand with the fist in the right hand again while saying "galagatung } \\
\text { ji." At "ji" each player points a finger to the right at the same time. If the fingers pointed by } \\
\text { the two players are the same, the game is over. The penalty is the base number obtained in } \\
\text { the third stage operated with a number in the operation determined in the fourth stage. But if } \\
\text { the fingers are different, the game continues, with the words uttered being "galagatung ro" } \\
\text { and so on. }\end{array}$ \\
\hline
\end{tabular}

As presented in Table 1, the first stage in the game of TTGJ is for every player to pick an identity for his-/herself and come up with a penalty to be imposed to the one to be punished. Suppose a group of four persons is playing the game as illustrated in Figure 1. The identities picked by the players are dragon, lion, gorilla, and dragonfly. The players, now identifying themselves as Dragon, Lion, Gorilla, and Dragonfly, take turn declaring their chosen penalties, for example, being flicked, performing squat-jumps and push-ups, and running in place. In this stage of the game, no mathematic concept is exhibited yet. 


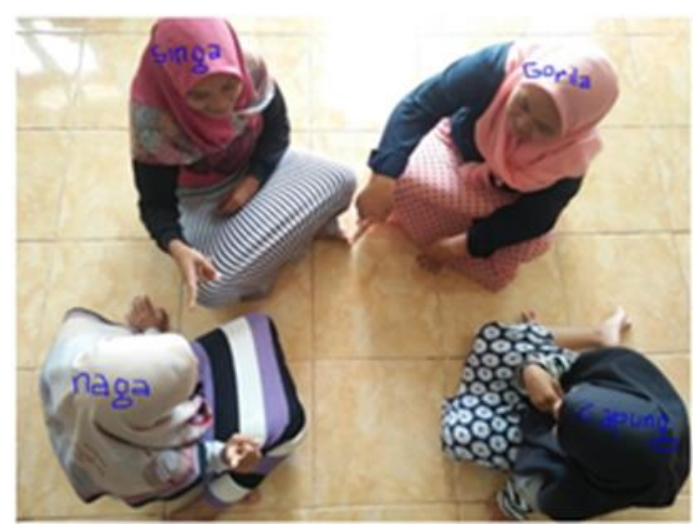

Figure 1. The first stage in the game of TTGJ.

Stage two starts with each player extending his/her fingers as shown in Figure 1. As seen in Figure 2, Dragon, Lion, Gorilla, and Dragonfly hold out 9, 5, 3, and 4 fingers, respectively. One of the players pointed at the extended fingers while uttering, "na-si-go-reng-ke-cap." Every syllable is to one finger. From the pointing at each finger, the last syllable said is "go". This means that Gorilla is out of the game. The determination of who should be eliminated can skip the pointing at extended fingers altogether and go with the application of the modular arithmetic concept.

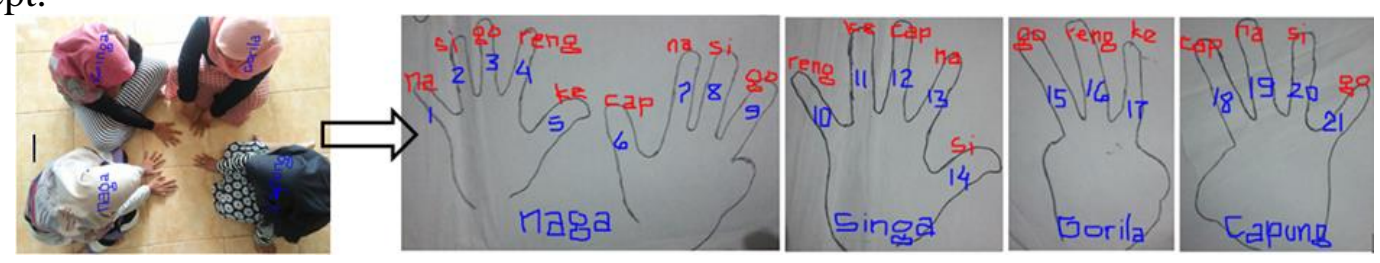

Figure 2. The second stage in the game of TTGJ

There are 6 syllables in the phrase nasi goreng kecap and 21 held out fingers from all players as shown in Figure 2. Twenty-one divided by 6 is 3, and the third syllable of the phrase nasi goreng kecap is "go." The syllable arrived at through this calculation is identical to that from pointing out of the fingers one by one. It is mathematically notated as $21 \bmod 6=3$, with 6 referred to as modulus and 3 being the remainder of the division of 21 by 6 . The results for the arithmetic module 6 belong to the set $\{0,1,2,3,4,5\}$ (Clark, 2003). If $a \bmod 6=r$, with $a$ being the number of extended fingers and $r$ the remainder of the division of $a$ by 6 , then the player that should go out from the game is determined by $r$. The relation between $r$ and which player is eliminated is laid down in Table 2.

Table 2. Animals which must be eliminated based on $r(a \bmod 6=r)$

\begin{tabular}{|c|c|}
\hline$r$ & Eliminated player (na-si-go-reng-ke-cap) \\
\hline 1 & Dragon \\
\hline 2 & Lion \\
\hline 3 & Gorilla \\
\hline 4 & Renggo (Rango) \\
\hline 5 & Bat \\
\hline 0 & Dragonfly \\
\hline
\end{tabular}

The third stage of the game of TTGJ is similar to the second stage in characteristics. The difference lies in the keywords used. In the third stage, the keyword is se-pa-tu, which is short for sepuloh, papat, pitu, or ten, four, and seven in English. Se-pa-tu consists of 3 syllables: se, pa, and tu. Each syllable is to one finger. The four players extend their fingers freely again as 
demonstrated in Figure 3. As seen in Figure 3, Dragon holds out 4 fingers, Lion 2, Gorilla 4, and Dragonfly 3. From the pointing at the fingers while spelling out se-pa-tu, a last syllable "se" was uttered. This means that the number I chosen is sepoloh (ten).

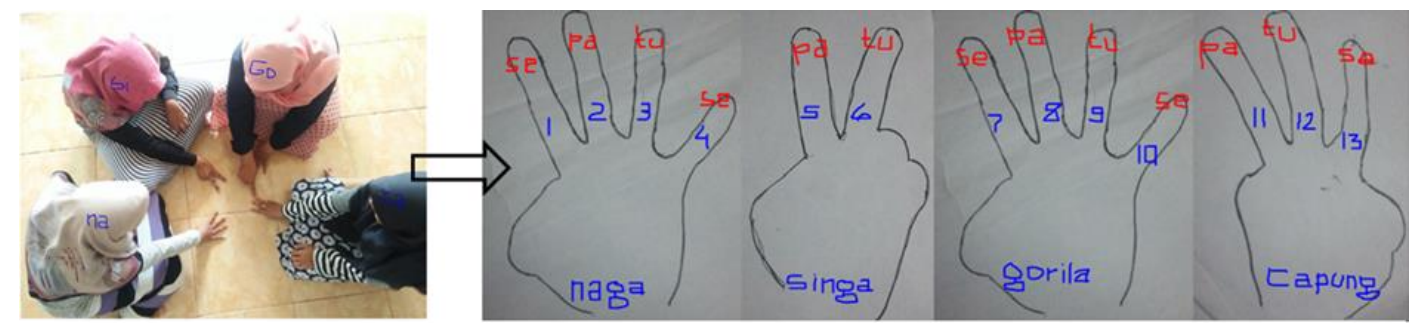

Figure 3. The third stage of the game of TTGJ

As in stage two, the modular arithmetic concept is applicable to stage three, too. There are 3 syllables in the word se-pa-tu, thus the number 3 is used as a modulus. The mathematical notation for stage three will be $13 \bmod 3=1$. A remainder of 1 from the arithmetic modulo 3 operation in stage three means that the syllable chosen is the first one, that is, "se." This is consistent with the last syllable obtained manually by finger-pointing. Hence, if $a \bmod 3=r$, with $a$ being the number of extended fingers and $r$ the remainder of the division of $a$ by 3 , then the number I selected is determined by $\boldsymbol{r}$. The relation between the results of the arithmetic modulo 3 operation and the number I selected is shown in Table 3.

Table 3. The number I selected based on $r(a \bmod 3=r)$

\begin{tabular}{ll}
\hline \multicolumn{1}{c}{$\mathrm{r}$} & Number I selected (se-pa-tu) \\
\hline 1 & Ten \\
2 & Four \\
0 & Seven \\
\hline
\end{tabular}

The fourth stage in the game of TTGJ shares similarities in characteristics with the third stage with a difference in the key expressions used, in which case stage 3 uses key words tambahkali-kurang. The finding of number I in stage 3 is followed by the determination of the operation to be performed. Unlike previous stages in which every single syllable is meant for one finger, this stage designates one word to one finger. The words used include tambah, kali, and kurang, which in English mean to add, to multiply, and to subtract, respectively. The four players extend their fingers freely again as shown in Figure 4.

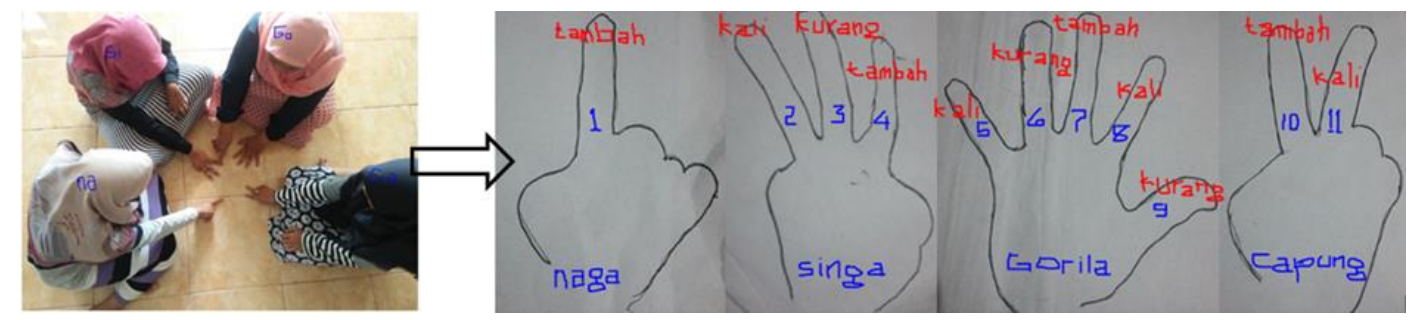

Figure 4. The fourth stage in the game of TTGJ

Figure 4 shows that Dragon holds out 1 finger, Lion 3, Gorilla 5, and Dragonfly 2. From pointing at fingers while saying tambah-kali-kurang, a last word "kali" was said. The implication is that the operation to be performed should be multiplication. Still, like previous stages, the concept of modular arithmetic can be applied in stage four. There are 3 words used, thus 3 is used as modulus. It is mathematically notated as $11 \bmod 3=2$. The remainder of 2 from the arithmetic modulo 3 operation in stage 4 means that the word selected is the second 
one, namely "kali." This process reaches the same word as the one yielded manually. Thus, if $a \bmod 3=r$, with $\boldsymbol{a}$ being the number of extended fingers and $\boldsymbol{r}$ the remainder of the division of $\boldsymbol{a}$ by 3, the arithmetic operation selected to be performed is determined by $\boldsymbol{r}$. The relation between the results of the arithmetic modulo 4 operation and the arithmetic operation selected can be seen in Table 4.

Table 4. Arithmetic operations chosen based on $r(a \bmod 3=r)$

\begin{tabular}{lll}
\hline & $\boldsymbol{r}$ & Selected operation (tambah-kali-kurang) \\
\hline 1 & Addition \\
\hline 2 & Multiplication \\
\hline 0 & Subtraction \\
\hline
\end{tabular}

The fifth stage is a stage where execution is to be imposed in a certain quantity to the punished player. Based on Table 1, this stage is played by 2 players, one the punished and the other the non-punished, one after the other. Suppose that from stage two it is determined that it is Dragonfly who will be punished, then in stage five he/she is to play against Lion as illustrated in Figure 5. Done with Lion, Dragonfly is to play against Dragon and, lastly, Gorilla.
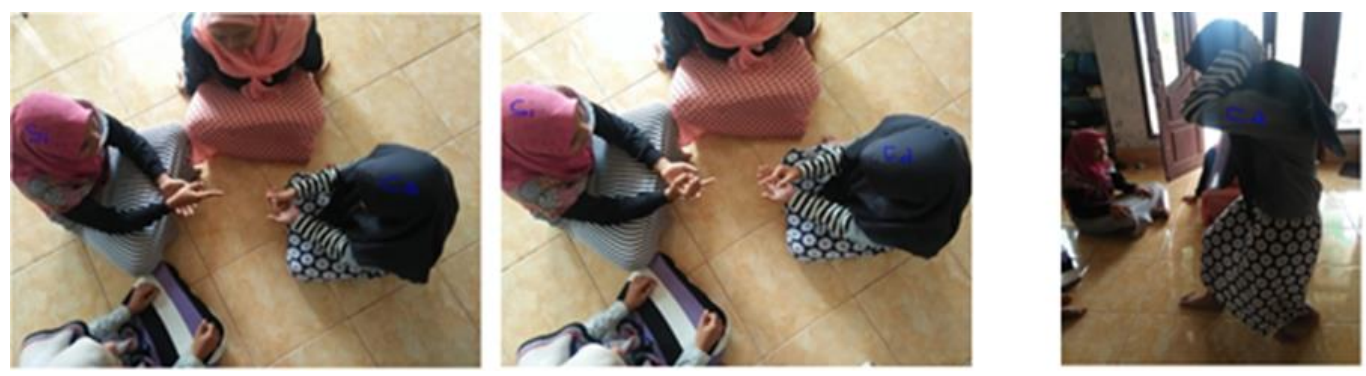

Figure 5. The fifth stage of the game of TTGJ

As can be seen in Figure 5, while saying TTGJ, the players have their right hand in a fist and their left hand held with palm opened face up under the right hand. At the time the syllable "ji" is called out, Dragonfly holds out his/her thumb, while Lion his/her index finger. This means that the game must go on with the players saying "galagatung ji." If the fingers extended are never the same, the game must be carried on with the players saying "galgatung ro," "galagatung lu," and so on until they hold out the same fingers. Ji, ro, and lu are short for siji, loro, and telu, the Javanese words for one, two, and three, respectively. Lion and Dragon finally show the same extended fingers when they say "galagatung mo." Mo is short for the word limo, which means five. Hence, number II which will be operated is a natural number smaller than 5, that is, 4 . This means that Lion is entitled to give a punishment of $40(10 \times 4)$ squat-jumps. The number 10 is obtained from stage three, the operation of multiplication in stage four, and the multiplier 4 in stage five. All possible combinations of selected number I, selected operation, and selected number II are presented in Table 5.

Table 5. Arithmetic operations in the game of TTGJ

\begin{tabular}{|c|c|c|}
\hline $\begin{array}{l}\text { Number } \\
\text { (stage three) }\end{array}$ & $\begin{array}{l}\text { I Arithmetic operation } \\
\text { (stage four) }\end{array}$ & $\begin{array}{l}\text { Punishment quantity } \\
\text { (stage five) }\end{array}$ \\
\hline \multirow{3}{*}{10} & Addition & $10+1 ; 10+2 ; 10+3 ; 10+4 ; \ldots ; 10+n, n \in \mathbb{N}$ \\
\hline & Multiplication & $10 \times 1 ; 10 \times 2 ; 10 \times 3 ; 10 \times 4 ; \ldots ; 10 \times \mathrm{n}, \mathrm{n} \in \mathbb{N}$ \\
\hline & Subtraction & $10-1 ; 10-2 ; 10-3 ; 10-4 ; \ldots ; 10-n, n \in \mathbb{N}$ \\
\hline \multirow{3}{*}{4} & Addition & $4+1 ; 4+2 ; 4+3 ; 4+4 ; \ldots ; 4+n, n \in \mathbb{N}$ \\
\hline & Multiplication & $4 \times 1 ; 4 \times 2 ; 4 \times 3 ; 4 \times 4 ; \ldots ; 4 \times n, n \in \mathbb{N}$ \\
\hline & Subtraction & $4-1 ; 4-2 ; 4-3 ; 4-4 ; \ldots ; 4-n, n \in \mathbb{N}$ \\
\hline
\end{tabular}




\begin{tabular}{lll}
\hline & Addition & $7+1 ; 7+2 ; 7+3 ; 7+4 ; \ldots ; 7+\mathrm{n}, \mathrm{n} \in \mathbb{N}$ \\
7 & $7 \times 1 ; 7 \times 2 ; 7 \times 3 ; 7 \times 4 ; \ldots ; 7 \times \mathrm{n}, \mathrm{n} \in \mathbb{N}$ \\
& Multiplication & $7-1 ; 7-2 ; 7-3 ; 7-4 ; \ldots ; 7-\mathrm{n}, \mathrm{n} \in \mathbb{N}$ \\
\hline
\end{tabular}

Table 5 shows basic mathematic operations (Brandt, Bassoi, \& Baccon, 2016; Rosenberg-Lee, Chang, Young, Wu, \& Menon, 2011) of addition, multiplication, and subtraction, but not division. In addition to basic mathematic operations, it also contains arithmetic sequences (Khalid \& Embong, 2020; Tohir, Abidin, Dafik, \& Hobri, 2018; Zazkis \& Liljedahl, 2002). For example, the second row of Table 5 contains the quotients of addition operations, namely 11 , $12,13, \ldots$. The first term of the sequence is 11 . The difference between the first and the second terms is 1 . Hence, the nth term is $U_{n}=11+(n-1) 1$ or $U_{n}=10+n$, with $n$ being a natural number. Natural numbers or $n$ in this game are used when the players say ji, ro, lu, and so on (Buijsman, 2019). The quantity of the punishment can be expressed in the form of a linear function (Moss, Boyce, \& Lamberg, 2020). Say, as given in Table 6, the number I selected is 10 , and the operation selected is the operation of addition, then the quantity of punishment to be imposed in stage five is given as $f(n)=10+n$ with $n$ and $f(n)$ being of natural numbers. The graph of the function can be seen in Graph 1.

Table 6. Addition operation in the game of TTGJ

\begin{tabular}{lll}
\hline $\begin{array}{l}\text { Number I } \\
\text { (stage three) }\end{array}$ & $\begin{array}{l}\text { Arithmetic operation } \\
\text { (stage } 4)\end{array}$ & $\begin{array}{l}\text { Punishment quantity } \\
\text { (stage } 5)\end{array}$ \\
\hline 10 & Addition & $10+1 ; 10+2 ; 10+3 ; 10+4 ; \ldots ; 10+\mathrm{n}, \mathrm{n} \in \mathbb{N}$ \\
\hline
\end{tabular}

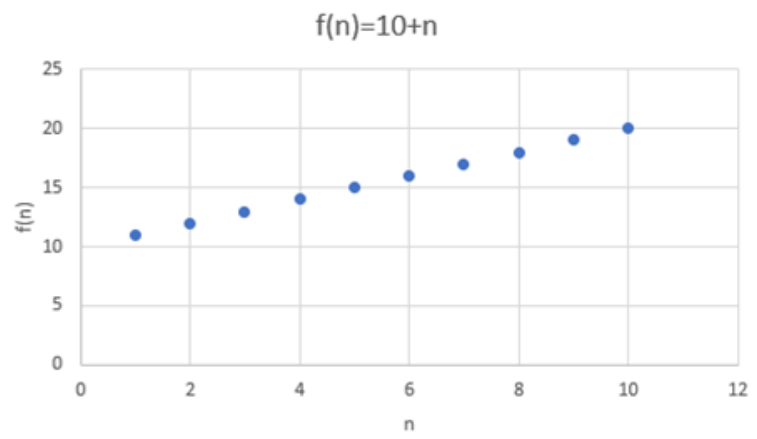

Graph 1. The graph for $f(n)=10+n$ in the game of TTGJ

In another instance, as shown in Table 7, the number I selected is 10 , and the operation selected is the operation of multiplication. Stage five can then be given as $f(n)=10 \times n$ with $n$ and $f(n)$ being of natural numbers. The graph for the function can be seen in Graph 2.

Table 7. Multiplication operation in the game of TTGJ

\begin{tabular}{lll}
\hline $\begin{array}{l}\text { Number I } \\
\text { (stage three) }\end{array}$ & $\begin{array}{l}\text { Arithmetic operation } \\
\text { (stage four) }\end{array}$ & $\begin{array}{l}\text { Punishment quantity } \\
\text { (stage five) }\end{array}$ \\
\hline 10 & Multiplication & $10 \times 1 ; 10 \times 2 ; 10 \times 3 ; 10 \times 4 ; \ldots ; 10 \times \mathrm{n}, \mathrm{n} \in \mathbb{N}$ \\
\hline
\end{tabular}


$f(n)=10 n$

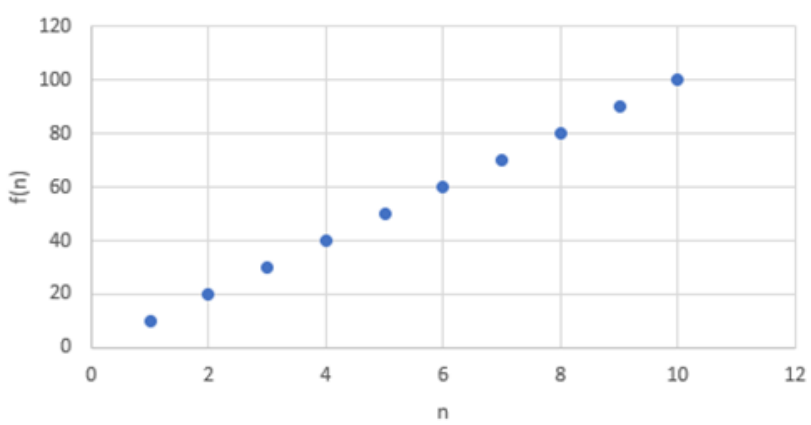

Graph 2. The graph for $f(n)=10 \times n$ in the game of TTGJ

Lastly, as given in Table 8, the number I selected is 10 , and the operation selection is the operation of subtraction. Then, stage five is given as $f(n)=10-n$ with $n$ and $f(n)$ being of natural numbers. The graph for the function can be seen in Graph 3.

Table 8. Arithmetic operation in the game of TTGJ

\begin{tabular}{lll}
$\begin{array}{l}\text { Number I } \\
\text { (stage three) }\end{array}$ & $\begin{array}{l}\text { Arithmetic operation } \\
\text { (stage four) }\end{array}$ & $\begin{array}{l}\text { Punishment quantity } \\
\text { (stage five) }\end{array}$ \\
\hline 10 & Subtraction & $10-1 ; 10-2 ; 10-3 ; 10-4 ; \ldots ; 10-\mathrm{n}, \mathrm{n} \in \mathbb{N}$
\end{tabular}

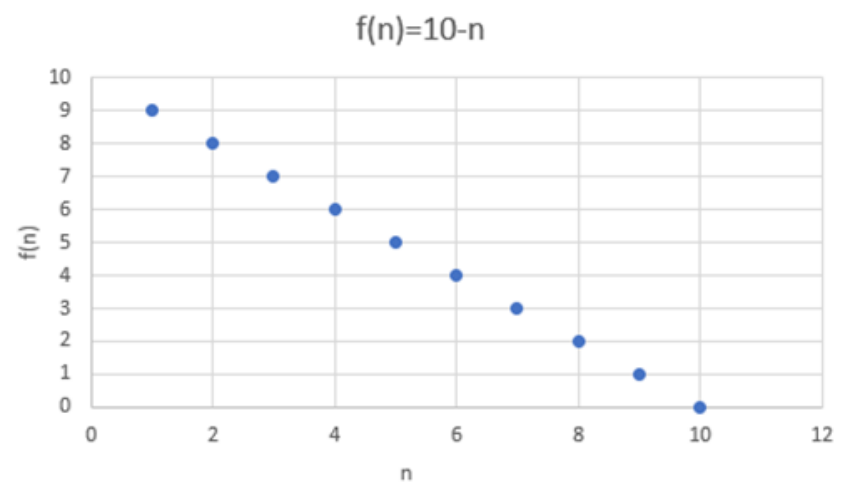

Graph 3. The graph for $f(n)=10-n$ in the game of TTGJ

As shown in Table 1, stage five featuring the players extending particular fingers indicates that the concept of probability is applied, in that each of two players is allowed to show any one of five possible fingers to the other. This counts as a case of independence because the probability of a finger extended by one player is not influenced by the probability of a finger extended by the other (Debnath \& Basu, 2015). Hence, in one event of finger extension, each finger has the probability of showing of $\frac{1}{5}$. Meanwhile, the probability of two players showing the same finger is $\left(\frac{1}{5} \times \frac{1}{5}\right)$ for each finger. As there are 5 fingers, the probability of same fingers extension occurrence is $5\left(\frac{1}{5} \times \frac{1}{5}\right)$. Accordingly, the probability of different fingers extension occurrence is $1-5\left(\frac{1}{5} \times \frac{1}{5}\right)$. This probability value is applicable only to a single time a finger is extended in the fifth stage in the game of TTGJ. Referring to the expected frequency, for an event of same fingers extension to occur, finger showing must be performed at least five times.

The mathematical concepts contained in the traditional game of TTGJ above are mathematics materials taught in high school (Allen \& Ross, 2017). Thus, the current set of TTGJ can be used 
in the learning process at school to create a realistic and fun learning atmosphere (De Gloria, Bellotti, \& Berta, 2014; Vlachopoulos \& Makri, 2017). Additionally, through the traditional game of TTGJ, students can train critical and creative thinking so that they have problemsolving skills (Dhayanti, Johar, \& Zubainur, 2018). For example, in the second stage of TTGJ, a player doesn't want to leave the game, then he can use the modulo concept to predict the number of fingers he has to stretch out in the game. Additionally, the traditional game of TTGJ can also grow some positive characters. This is shown at the first stage of TTGJ when players choose and determine their identity. So that can train an independent attitude, self-confidence, and awareness of the rights and obligations of self and others. Furthermore, in the second through fifth stages, you can practice being responsible for the decisions and the actions he takes during the game

\section{Conclusion}

The results of the study show (novelty of the research) that ethnomathematical elements are present in the traditional game TTGJ in every stage of the game. Stage two features the concept of arithmetic modulo 6 operation in the pointing at the players' fingers while saying the keyword syllables "na-si-go-reng-ke-cap" in cycles. Stage three features the concept of arithmetic modulo 3 operation in the pointing at the players' fingers while saying the keyword syllables "se-pa-tu" in cycles. Stage four also features the concept of arithmetic modulo 3 operation in the pointing at the players' fingers, but it is done while uttering three words (tambah-kali-kurang) in cycles. Stage five features basic mathematic operations of addition, subtraction, and multiplication (division excluded), as well as the concept of arithmetic sequence during the determination of punishment quantity. Punishment quantity is determined by operating any one of the numbers 10,4 , and 7 decided on in stage three with a natural number (ji, ro, lu, .., n) in stage five. The concept of probability also appears in stage five during simultaneous finger showing.

\section{References}

Alghadari, F., \& Son, A. L. (2018). Teori dan kemampuan matematis dalam permainan kartu Gaple: Kajian etnomatematika. WACANA AKADEMIKA: Majalah Ilmiah Kependidikan, 2(1), 25-37. https://doi.org/10.30738/wa.v2i1.1984

Allen, G. D., \& Ross, A. (2017). Pedagogy and content in middle and high school mathematics. In Pedagogy and Content in Middle and High School Mathematics. https://doi.org/10.1007/978-94-6351-137-7

Brandt, C. F., Bassoi, T. S., \& Baccon, A. L. P. (2016). Difficulties of 6th grade elementary school students in solving the four basic fundamental operations: Addition, subtraction, multiplication and division of natural numbers. Creative Education. https://doi.org/10.4236/ce.2016.713185

Buijsman, S. (2019). Learning the Natural Numbers as a Child. Nous, 53(1), 3-22. https://doi.org/10.1111/nous.12219

Clark, W. E. (2003). Elementary Number Theory. Retrieved from http://joshua.smcvt.edu/numbertheory/book.pdf

De Gloria, A., Bellotti, F., \& Berta, R. (2014). Serious Games for education and training. International Journal of Serious Games, 1(1), 1-15. https://doi.org/10.17083/ijsg.v1i1.11

Debnath, L., \& Basu, K. (2015). A short history of probability theory and its applications. International Journal of Mathematical Education in Science and Technology, 46(1), 1339. https://doi.org/10.1080/0020739X.2014.936975

Dhayanti, D., Johar, R., \& Zubainur, C. M. (2018). Improving Students' Critical and Creative Thinking through Realistic Mathematics Education using Geometer's Sketchpad. 
JRAMathEdu (Journal of Research and Advances in Mathematics Education), 3(1), 25. https://doi.org/10.23917/jramathedu.v3i1.5618

Dosinaeng, W. B. N. (2010). Analisis pemikiran matematis dalam permainan tradisional masyarakat lamaholot. Prosiding Seminar Nasional Etnomatnesia, 491-498. Retrieved from http://jurnal.ustjogja.ac.id/index.php/etnomatnesia/article/view/2370

Febriyanti, C., Kencanawaty, G., \& Irawan, A. (2019). Etnomatematika Permainan Kelereng. MaPan, 7(1), 32-40. https://doi.org/10.24252/mapan.2019v7n1a3

Febriyanti, C., Prasetya, R., \& Irawan, A. (2018). Etnomatematika pada permainan tradisional engklek dan gasing khas kebudayaan sunda. BAREKENG: Jurnal Ilmu Matematika Dan Terapan, 12(1), 1-6. https://doi.org/10.30598/vol12iss1pp1-6ar358

Fitriatien, S. R. (2017). Pembelajaran Berbasis Etnomatematika. (December 2016).

Fouze, A. Q., \& Amit, M. (2018). Development of mathematical thinking through integration of ethnomathematic folklore game in math instruction. Eurasia Journal of Mathematics, Science and Technology Education, 14(2), 617-630. https://doi.org/10.12973/ejmste/80626

Jaelani, A., Putri, R. I. I., \& Hartono, Y. (2013). Students' Strategies of Measuring Time Using Traditional Gasing Game in Third Grade of Primary School. IndoMS. J.M.E, 4(1), 29-40. Retrieved from https://ejournal.unsri.ac.id/index.php/jme/article/view/560

Johnson, J. (2017). A topic revisited : students in the republic of the Maldives writing contextual word problems. IEJME - Mathematics Education, 12(5), 549-559. Retrieved from https://www.iejme.com/article/a-topic-revisited-students-in-the-republic-of-themaldives-writing-contextual-word-problems

Khalid, M., \& Embong, Z. (2020). Sources and Possible Causes of Errors and Misconceptions in Operations of Integers. 15(2). https://doi.org/https://doi.org/10.29333/iejme/6265

Massarwe, K., Verner, I., \& Bshouty, D. (2013). Ethnomathematics and Multi-Cultural Education: Analysis and Construction of Geometric Ornaments Journal of Mathematics and Culture. Journal of Chemical Information and Modeling. https://doi.org/10.1017/CBO9781107415324.004

Moss, D. L., Boyce, S., \& Lamberg, T. (2020). Representations and Conceptions of Variables in Students , Early Understandings of Functions. 15(2). https://doi.org/10.29333/iejme/6257

Muslimin, M. (2012). Desain Pembelajaran Pengurangan Bilangan Bulat Melalui Permainan Tradisional Congklak Berbasis Pendidikan Matematika Realistik Indonesia di Kelas IV Sekolah Dasar. Kreano: Jurnal Matematika Kreatif-Inovatif. https://doi.org/10.15294/kreano.v3i2.2642

Muzdalipah, I., \& Yuliaanto, E. (2015). Pengembangan desain pembelajaran matematika untuk siswa sd berbasis aktivitas budaya dan permainan tradisional masyarakat kampung Naga. Jurnal Siliwangi, $1(1), \quad 63-74 . \quad$ Retrieved from http://jurnal.unsil.ac.id/index.php/jspendidikan/article/view/18

Nofrianto, A. (2015). Etnomathematics (Mathematical concepts in Minangkabau traditional game). Proceeding of The International Conference on Mathematics, Science, Education and Technology (ICOMSET), 3(2), 1-4. Retrieved from http://seminar.fmipa.unp.ac.id/icomset/

Rahmawati, N. P., \& Dintarini, M. (2020). Implementation of Patil Lele Traditional Game As Ethnomathematics to Improve Student's Perspective to Mathematics. MEJ (Mathematics Education Journal), 3(2), 130-138. Retrieved from http://ejournal.umm.ac.id/index.php/MEJ/article/view/11070

Risdiyanti, I., Charitas, R., \& Prahmana, I. (2018). Etnomatematika: Eksplorasi dalam permainan. Journal of Medives: Journal of Mathematics Education IKIP Veteran Semarang, 2(1), 1-11. Retrieved from http://e- 
journal.ivet.ac.id/index.php/matematika/article/view/562

Risdiyanti, I., \& Prahmana, R. C. I. (2018). Ethnomathematics: Exploration in Javanese culture. Journal of Physics: Conference Series, 943(1). https://doi.org/10.1088/17426596/943/1/012032

Rosenberg-Lee, M., Chang, T. T., Young, C. B., Wu, S., \& Menon, V. (2011). Functional dissociations between four basic arithmetic operations in the human posterior parietal cortex: A cytoarchitectonic mapping study. Neuropsychologia, 49(9), 2592-2608. https://doi.org/10.1016/j.neuropsychologia.2011.04.035

Safitri, D., Hartoyo, A., \& Nursang, A. (2015). Eksplorasi konsep matematika pada permainan masyarakat melayu sambas. Jurnal Pendidikan Dan Pembelajaran Khatulistiwa, 4(6), 114. Retrieved from http://jurnal.untan.ac.id/index.php/jpdpb/article/view/10350

Simamora, R. E., Saragih, S., \& Hasratuddin, H. (2018). Improving students' mathematical problem solving ability and self-efficacy through guided discovery learning in local culture context. International Electronic Journal of Mathematics Education, 14(1), 6172. https://doi.org/10.12973/iejme/3966

Siregar, S. N., Solfitri, T., \& Roza, Y. (2018). Pengenalan Konsep Operasi Hitung Bilangan Melalui Permainan Congklak Dalam Pembelajaran Matematika. Al-Khwarizmi: Jurnal Pendidikan Matematika Dan Ilmu Pengetahuan Alam, 2(1), 119-128. https://doi.org/10.24256/jpmipa.v2i1.107

Suherman, S. (2018). Ethnomathematics : Eksploration of Traditional Crafts Tapis Lampung as Ilustration of Science, Technology, Engineering, and Mathematics (STEM). Eduma: Mathematics Education Learning and Teaching, 7(2). https://doi.org/10.24235/eduma.v7i2.3085

Susanti, E., Sholikin, N. W., Marhayati, M., \& Turmudi, T. (2020). Designing culturally-rich local games for mathematics learning. Beta: Jurnal Tadris Matematika, 13(1), 49-60. https://doi.org/10.20414/betajtm.v13i1.354

Tohir, M., Abidin, Z., Dafik, D., \& Hobri, H. (2018). Students creative thinking skills in solving two dimensional arithmetic series through research-based learning. Journal of Physics: Conference Series. https://doi.org/10.1088/1742-6596/1008/1/012072

Utami, N. I., Holisin, I., \& Mursyidah, H. (2018). The Development of Engklek Geometri Learning Media to Preserve Traditional Game. Formatif: Jurnal Ilmiah Pendidikan MIPA, 8(3), 1-14. https://doi.org/10.30998/formatif.v8i3.2710

Utami, T. N., Jatmiko, A., \& Suherman, S. (2018). Pengembangan Modul Matematika dengan Pendekatan Science, Technology, Engineering, And Mathematics (STEM) pada Materi Segiempat. Desimal: Jurnal Matematika, 165. https://doi.org/10.24042/djm.v1i2.2388

Vandercruysse, S., Ter Vrugte, J., De Jong, T., Wouters, P., Van Oostendorp, H., Verschaffel, L., ... Elen, J. (2016). The effectiveness of a math game: The impact of integrating conceptual clarification as support. Computers in Human Behavior, 64(November), 2133. https://doi.org/10.1016/j.chb.2016.06.004

Verner, I., Massarwe, K., \& Bshouty, D. (2019). Development of competencies for teaching geometry through an ethnomathematical approach. Journal of Mathematical Behavior, 56(1), 1-14. https://doi.org/10.1016/j.jmathb.2019.05.002

Vlachopoulos, D., \& Makri, A. (2017). The effect of games and simulations on higher education: a systematic literature review. In International Journal of Educational Technology in Higher Education (Vol. 14). https://doi.org/10.1186/s41239-017-0062-1

Yusuf, M. W., Saidu, I., \& Halliru, A. (2010). Ethnomathematics (A mathematical game in hausa culture). International Journal of Mathematical Science Education, 3(1), 36-42. Retrieved from https://www.mendeley.com/catalogue/f26983b7-ef61-3502-8626e0eb4caea5bd/ 
Zayyadi, M. (2015). Eksplorasi etnomatematika pada batik madura. Sigma, 2(2), 35-40.

Zazkis, R., \& Liljedahl, P. (2002). Arithmetic sequence as a bridge between conceptual fields. Canadian Journal of Science, Mathematics and Technology Education. https://doi.org/10.1080/14926150209556501

Zhang, W. \& Q. Z. (2010). Ethnomathematics and Its Integration within the Mathematics Curriculum. Journal of Mathematics Education, 3(1), 151-157. 